\title{
TUMOR KEPALA LEHER DI POLIKLINIK THT-KL RSUP PROF. DR. R. D. KANDOU MANADO PERIODE JANUARI 2010 - DESEMBER 2012
}

\author{
${ }^{1}$ Taruli Hutauruk \\ ${ }^{2}$ Olivia Pelealu \\ ${ }^{3}$ Ora I. Palandeng
}

\author{
Kandidat Fakultas Kedokteran Unsrat \\ Bagian Telinga Hidung Tenggorok Kepala dan Leher (THT-KL) Fakultas Kedokteran \\ Universitas Sam Ratulangi \\ Email: Lady_inthew19@yahoo.com
}

\begin{abstract}
Abstrak: Tumor dalam istilah umum adalah pertumbuhan massa atau jaringan abnormal dalam tubuh. Tumor terbagi menjadi 2 yaitu tumor jinak dan tumor ganas. Manifestasinya dapat berbagai bentuk, mulai dari lesi kecil, massa atau granulasi sampai dengan tumor yang sudah meluas. Letak tumor Telinga Hidung Tenggorok Kepala dan Leher (THT-KL) yang tersembunyi dan gejala yang tidak khas menyebabkan sulitnya diagnosa dini. Tumor ganas THT-KL merupakan 5\% dari seluruh penyakit keganasan di Amerika Serikat. Tujuan ini untuk mengetahui penderita Tumor Kepala Leher di bagian/SMF THT- KL RSU Prof. dr. R. D. Kandou Manado periode Januari 2010-Desember 2012. Rancangan Penelitian ini dilakukan dengan menggunakan metode retrospektif deskriptif melalui pengumpulan data. Pengambilan sampel penelitian adalah secara retrospektif dengan melihat rekam medik yaitu seluruh penderita tumor THT-KL yang datang ke bagian/SMF THT-KL BLU Prof. dr. R. D. Kandou sejak bulan Januari 2010-Desember 2012. Pada penelitian ini dijumpai penderita tumor THT-KL pada Januari 2010-Desember 2012 sebanyak 231 penderita dan paling banyak ditemukan pada laki-laki (68.9\%), kelompok umur terbanyak adalah 41-65 tahun $(46,3 \%)$ dengan kelompok umur termuda $0-5$ tahun $(0,87 \%)$, jenis histopatologis terbanyak yaitu karsinoma sel skuamosa $(4,7 \%)$ dan lokasi tumor tersering yaitu nasofaring $(35,1 \%)$.
\end{abstract}

Kata Kunci: tumor kepala leher, retrospektif deskriptif, penderita

Background: Tumor in general terms is a mass or growth of abnormal tissue in the body. There are 2 types of tumor benign tumors and malignant tumors. THT-KL tumor is $5 \%$ among all malignant disease in United States. Approximately 95\% of malignant tumors in the THT-KL is carcinoma cell squamous, which is ranked $6^{\text {th }}$ among all tumors in the world. Indonesia is one the countries with the high prevalence of nasopharyngeal carcinoma exclude China. Smoking and alcohol drinking are the etiologic factors that are often found in THT-KL. Radiotherapy is a major treatment or by surgery. To determine patients with the Head and Neck Tumor in the THT-KL RSU Prof. dr. R. D. Kandou Hospital Manado January 2010-December 2012 periode. The study design was done by using retrospective descriptive method through data obtained. Sampling collected by retrospective method using medical records of all patients with THT-KL tumors-which comes to THT-KL Prof. dr. R. D. Kandou since January 2010December 2012. In this study, patients with tumors found THT-KL in January 2010-December 2012 as many as 231 patients and most commonly found in men $(68.9 \%)$, the largest age group was 41-65 years $(46.3 \%)$ by age group youngest $0-5$ years $(0.87 \%)$, of which the most histopathologic examination squamous cell carcinoma (4.7\%) and the most common location of nasopharyngeal tumors $(35.1 \%)$ 
Keywords: head neck tumors, retrospective descriptive, patients

Tumor dalam istilah umum adalah pertumbuhan massa atau jaringan abnormal dalam tubuh. Tumor terbagi menjadi 2 yaitu tumor jinak dan tumor ganas. Manifestasinya dapat berbagai bentuk, mulai dari lesi kecil, massa atau granulasi sampai dengan tumor yang sudah meluas. Letak tumor Telinga Hidung Tenggorok Kepala dan Leher (THT-KL) yang tersembunyi dan gejala yang tidak khas menyebabkan sulitnya diagnosa dini. ${ }^{1}$

Tumor ganas THT-KL merupakan 5\% dari seluruh penyakit keganasan di Amerika Serikat. Pada setiap tahunnya terdiagnosa lebih kurang 40.000 kasus tumor ganas kepala leher, dari jumlah tersebut 11.500 pasien meninggal tiap tahunnya. Lebih dari $70 \%$ pasien datang dengan stadium lanjut (stadium III dan IV), secara histopatologi 90\% merupakan karsinoma sel skuamosa. $^{2}$

Di Amerika Utara dan Eropa terjadi pada pria usia pertengahan yang mempunyai riwayat pengidap kronik dari merokok tembakau dan alkohol. Sekitar 50\% karsinoma sel skuamous yg timbul pada orofarings, tonsil, dan pangkal lidah. Ditaksir ada 45.000 kasus di Amerika Serikat (A.S) dan lebih dari 650.000 kasus diseluruh dunia yg didiagnosa setiap tahun. Insiden karsinoma nasofaring tertinggi di dunia dijumpai pada penduduk daratan Cina bagian selatan dengan angka mencapai lebih dari 50 per 100.000 penduduk pertahun.

Tumor ganas nasofaring, hidung dan sinus paranasal serta laring merupakan 3 keganasan yang paling banyak ditemukan pada tumor ganas kepala dan leher, kemudian tumor ganas orofaring, telinga, esofagus/bronkus, dan mulut. ${ }^{2}$

Sekitar 5\% semua tumor ganas pada pria dan $2 \%$ pada wanita berasal dari THT-KL. Terdapat lebih dari 50.000 kasus baru kanker kepala dan leher yang muncul setiap tahunnya di Amerika Serikat, dan terdapat lebih dari 15.000 kematian per tahunnya. Di seluruh dunia, karsinoma sel skuamosa kepala dan leher mengenai lebih dari 500.000 orang per tahunnya.

Kira-kira 95\% tumor ganas pada THT-KL adalah karsinoma sel skuamous. Merupakan keganasan epitelial yg agresif, berada pada peringkat ke-6 dari tumor di seluruh dunia. ${ }^{3}$

Indonesia termasuk salah satu negara dengan prevalensi penderita karsinoma nasofaring yang termasuk tinggi di luar Cina. Data registrasi kanker di Indonesia berdasarkan histopatologi tahun 2003 menunjukan bahwa karsinoma nasofaring menempati urutan pertama dari semua tumor ganas primer pada laki - laki dan urutan ke 8 pada perempuan. ${ }^{3}$

Dari penjelasan diatas dapat kita temukan bahwa tumor di bagian THT-KL dapat menyebabkan kematian jika tidak ditolong secepatnya. Hal inilah yang mendorong penulis untuk mengadakan penelitian tentang pola penderita tumor Telinga Hidung Tenggorok Kepala dan Leher (THT-KL) di poliklinik THT-KL RSU Prof. Dr. R D. Kandou periode 2010 Desember 2012.

\section{METODE PENELITIAN}

Penelitian ini dilakukan dengan menggunakan metode retrospektif deskriptif melalui pengumpulan data yang dilakukan di Bagian/SMF THT-KL BLU Prof. dr. R. D. Kandou Manado untuk mendapat data tentang penderita tumor. Penelitian dilakukan pada bulan November 2012 - Desember 2012. 


\section{Populasi dan Sampel penelitian}

Penderita yang datang ke Bagian/SMF THT-KL BLU Prof. dr. R. D. Kandou Manado dan terdiagnosis secara klinis dan/atau histopatologis dan/atau endoskopis sebagai tumor.

\section{Instrumen Penelitian}

1. Alat tulis menulis

2. Status penderita dan buku register di Bagian/SMF THT-KL BLU RSU Prof. dr. R. D. Kandou Manado periode Januari 2010-Desember 2012

3. Buku registrasi endoskopi di Bagian/SMF THT-KL BLU RSU Prof. dr. R. D. Kandou Manado periode Januari 2010-Desember 2012

4. Literatur yang berhubungan dengan karya tulis ini

5. Checklist penelitian

\section{Cara Kerja}

1. Mengumpulkan data penderita tumor secara retrospektif dari catatan medis penderita dan buku register di bagian/SMF THT-KL BLU RSU Prof. dr. R. D. Kandou Manado periode Januari 2010-Desember 2012

2. Mengolah data kasus dengan cara disusun dalam bentuk tabel dan grafik serta presentase yang mencakup:

a. Distribusi frekuensi penderita tumor berdasarkan tahun kejadian tumor di bagian/SMF THT-KL BLU RSU Prof. dr. R. D. Kandou Manado periode Januari 2010 - Desember 2012

b. Distribusi frekuensi penderita tumor berdasarkan jenis kelamin, umur dan jenis pekerjaan.

c. Distribusi frekuensi penderita tumor berdasarkan gambaran histopatologis yang ditemukan

d. Distribusi frekuensi penderita tumor berdasarkan lokasi tumor yang ditemukan.

\section{Definisi Operasional}

1. Tumor adalah pertumbuhan jaringan sel abnormal yang disebut neoplasma dan yang terdiagnosis secara klinis dan/atau histopatologis dan/atau endoskopis sebagai tumor.

2. Jenis kelamin adalah jenis kelamin penderita tumor yang tercatat pada laporan catatan medik.

3. Umur adalah umur penderita pada saat datang berobat pada periode Januari 2010-Desember 2012.

4. Pekerjaan adalah segala sesuatu yang dikerjakan penderita dalam mencukupi kebutuhan hidup, saat pertama kali penderita datang berobat.

5. Gambaran histopatologis adalah gambaran berupa pemeriksaan histopatologis yang dilakukan oleh penderita

6. Lokasi tumor adalah tumor yang ditemukan pada saat terdiagnosis secara klinis dan/atau histopatologis dan/atau endoskopis sebagai tumor.

\section{HASIL PENELITIAN}


Hasil penelitian yang telah dilakukan di bagian/SMF THT-KL RSU Prof. dr. R. D. Kandou Manado periode Januari 2010-Desember 2012 didapatkan sebanyak 231 penderita yang terdiagnosis secara klinis dan/atau endoskopis sebagai tumor kepala leher.

Tabel 4.1 Distribusi Penderita Tumor Kepala Leher Berdasarkan Tahun Kejadian di bagian/SMF THT - KL RSU Prof. dr. R. D. Kandou Manado periode Januari 2010-Desember 2012

\begin{tabular}{lccc}
\hline Tahun & Jumlah Pengunjung & Jumlah Penderita & \% \\
\hline 2010 & 4227 & 88 & 2,09 \\
2011 & 4295 & 88 & 2,05 \\
2012 & 4459 & 55 & 1,24 \\
\hline Total & $\mathbf{1 2 9 8 1}$ & $\mathbf{2 3 1}$ & $\mathbf{1 . 7 8}$ \\
\hline
\end{tabular}

Pada tabel 4.1 tampak bahwa kasus tumor kepala leher sebanyak 231 penderita dari pengunjung yang datang berobat di bagian/SMF THT-KL RSU Prof. dr. R. D. Kandou Manado periode Januari 2010 - Desember 2012. Tahun 2010 dan 2011 merupakan angka kejadian tertinggi, yaitu sebanyak 88 penderita.

Tabel 4.2 Distribusi Penderita Tumor Kepala Leher Berdasarkan Jenis Kelamin

\begin{tabular}{lccccc}
\hline Jenis Kelamin & $\mathbf{2 0 1 0}$ & $\mathbf{2 0 1 1}$ & $\mathbf{2 0 1 2}$ & $\mathbf{n}$ & \% \\
\hline Laki-laki & & & & & \\
Perempuan & 56 & 25 & 15 & 72 & 31,1 \\
\hline Total & 32 & $\mathbf{8 8}$ & $\mathbf{5 5}$ & $\mathbf{2 3 1}$ & $\mathbf{1 0 0}$ \\
\hline
\end{tabular}

Distribusi penderita tumor kepala leher berdasarkan jenis kelamin ditampilkan dalam tabel 4.2, yang menunjukkan jumlah penderita laki-laki sebanyak 158 penderita (68.9\%) dan perempuan sebanyak 72 penderita $(31.1 \%)$.

Tabel 4.3 Distribusi Penderita Tumor Kepala Leher Berdasarkan Umur

\begin{tabular}{lccccc}
\hline Umur & $\mathbf{2 0 1 0}$ & $\mathbf{2 0 1 1}$ & $\mathbf{2 0 1 2}$ & $\mathbf{n}$ & \% \\
\hline $0-5$ & 1 & 1 & - & 2 & 0,87 \\
$6-11$ & - & 1 & 4 & 5 & 2,17 \\
$12-17$ & 5 & 2 & 1 & 8 & 3,47 \\
$18-40$ & 21 & 22 & 19 & 62 & 26,9 \\
$41-65$ & 37 & 47 & 23 & 107 & 46,3 \\
\hline
\end{tabular}




\begin{tabular}{lccccc}
\hline$\geq 65$ & 24 & 9 & 3 & 36 & 15,6 \\
Tidak ada/Lainnya & - & 6 & 5 & 11 & 4,77 \\
\hline Total & $\mathbf{8 8}$ & $\mathbf{8 8}$ & $\mathbf{5 5}$ & $\mathbf{2 3 1}$ & $\mathbf{1 0 0}$ \\
\hline
\end{tabular}

Pada tabel 4.3 ditemukan bahwa kelompok umur yang paling banyak yaitu pada kelompok umur 41-65 tahun, yaitu sebanyak 107 penderita, Sedangkan kelompok umur dibawah 5 tahun adalah yang paling rendah.

Tabel 4.4 Distribusi Penderita Tumor Kepala Leher Berdasarkan Jenis Pekerjaan

\begin{tabular}{lccccc}
\hline Jenis Pekerjaan & $\mathbf{2 0 1 0}$ & $\mathbf{2 0 1 1}$ & $\mathbf{2 0 1 2}$ & $\mathbf{n}$ & $\mathbf{\%}$ \\
\hline Petani & 16 & 2 & 6 & 24 & 10,2 \\
Pensiunan & 16 & 9 & 6 & 31 & 13,2 \\
IRT & 13 & 4 & 2 & 19 & 8,3 \\
Sopir & 2 & 3 & - & 5 & 2,2 \\
Pegawai & 3 & 3 & 5 & 11 & 4,8 \\
Swasta & 7 & 6 & 3 & 16 & 7,0 \\
Buruh & 3 & 1 & 2 & 6 & 2,6 \\
Siswa & 1 & 2 & 1 & 4 & 1,8 \\
Guru & - & - & 1 & 1 & 0,5 \\
Tidak ada/Lainnya & 27 & 58 & 29 & 114 & 49,4 \\
\hline Total & $\mathbf{8 8}$ & $\mathbf{8 8}$ & $\mathbf{5 5}$ & $\mathbf{2 3 1}$ & $\mathbf{1 0 0}$ \\
\hline
\end{tabular}

Pada tabel 4.4 tampak bahwa penderita yang tidak mempunyai pekerjaan/tidak tercantum di buku register berobat di bagian/SMF THT-KL RSU Prof. dr. R. D. Kandou Manado periode Januari 2010-Desember 2012 merupakan yang paling banyak, yaitu sebesar 114 penderita (49.4\%) dan diikuti dengan pensiunan sebesar 31 penderita (13.2\%).

Tabel 4.5 Distribusi Penderita Tumor Kepala Leher Berdasarkan Gambaran Histopatologis

\begin{tabular}{lcc}
\hline Tahun & $\mathbf{N}$ & $\%$ \\
\hline Karsinoma sel skuamous & 11 & 4,7 \\
Adenocarcinoma & 7 & 3 \\
\hline
\end{tabular}




\begin{tabular}{lcc}
\hline Angioma & 1 & 0,5 \\
Angiofibroma & 2 & 0,8 \\
Tanpa pemeriksaan Histopatologis & 210 & 91 \\
\hline Total & $\mathbf{2 3 1}$ & $\mathbf{1 0 0}$ \\
\hline
\end{tabular}

Pada tabel 4.5 dapat dilihat bahwa kasus tumor kepala leher tanpa pemeriksaan histopatologis merupakan kasus yang paling banyak, sedangkan karsinoma sel skuamous merupakan gambaran histopatologis yang tersering dari kasus yang melakukan pemeriksaan histopatologis.

Tabel 4.6 Distribusi Penderita Tumor Kepala Leher Berdasarkan Lokasi Tumor

\begin{tabular}{lccccc}
\hline Lokasi Tumor & $\mathbf{2 0 1 0}$ & $\mathbf{2 0 1 1}$ & $\mathbf{2 0 1 2}$ & $\mathbf{n}$ & \% \\
\hline Telinga & - & 2 & - & 2 & 0,9 \\
Hidung dan Sinus Paranasal & 20 & 17 & 20 & 57 & 24,6 \\
Mulut & 8 & 5 & 1 & 14 & 6,0 \\
Nasofaring & 30 & 30 & 21 & 81 & 35,1 \\
Orofaring & - & 8 & 4 & 12 & 5,2 \\
Hipofaring & - & 2 & 1 & 3 & 1,3 \\
Laring & 30 & 24 & 8 & 62 & 26,9 \\
\hline Total & $\mathbf{8 8}$ & $\mathbf{8 8}$ & $\mathbf{5 5}$ & $\mathbf{2 3 1}$ & $\mathbf{1 0 0}$ \\
\hline
\end{tabular}

Pada tabel 4.6 dapat dilihat bahwa lokasi tumor terbanyak adalah kasus tumor nasofaring sebesar 81 penderita (35.1\%) diikuti oleh tumor laring 62 penderita (26.9\%).

\section{BAHASAN}

Berdasarkan penelitian yang telah dilakukan di Bagian/SMF THT-KL RSU Prof.dr. R. D. Kandou Manado periode Januari 2010-Desember 2012 pada Tabel 4.1, didapatkan sebanyak 231 penderita dari 12981 pengunjung yang datang berobat. Tahun 2012 mengalami penurunan jumlah kasus dibandingkan dua tahun sebelumnya, sehingga tahun 2012 merupakan angka kejadian terendah.

Pada Tabel 4.2 terlihat kelompok jenis kelamin penderita terbanyak adalah laki-laki sebanyak 159 penderita $(68,9 \%)$ dan perempuan 72 penderita $(31,1 \%)$ dari 231 penderita, dimana perbandingannya 2:1. Muzakkir pada Januari 2006 sampai desember 2010 sebanyak 
589 penderita dan paling banyak ditemukan pada laki-laki ( $72,84 \%$ ). Sihotang ZB dalam penelitiannya di RSUP H Adam Malik Medan yang dilakukan sejak Juni 2007 sampai Desember 2007 mendapatkan jenis kelamin penderita terbanyak adalah laki-laki 77,3\% dan perempuan $22,7 \%$. $^{2,4}$

Hasil yang di dapat peneliti terlihat jenis kelamin laki-laki yang terbanyak, dan ini hampir sama dengan hasil penelitian yang dilakukan oleh beberapa peneliti yang lain. Tingginya persentasi laki-laki dibandingkan perempuan kemungkinan disebabkan oleh faktor kebiasaan dari laki-laki yang berbeda dengan perempuan, dimana laki-laki lebih terbuka untuk mendapatkan paparan dari berbagai bahan-bahan karsinogen, baik akibat dari pekerjaan maupun ligkungan yang di dapatinya. Merokok dan minum alkohol adalah faktor etiologi yang sering ditemukan pada tumor ganas THT-KL. ${ }^{5}$

Pada Tabel 4.3 kelompok umur terbanyak adalah 41-65 sebanyak 107 penderita (46,3\%), yang paling sedikit 0-5 tahun (0.87\%). Harjono di Surabaya dalam penelitiannya mendapatkan kelompok umur terbanyak adalah 40-60 tahun ( 67,3\% ). Nagar dalam penelitiannya pada tahun 2004 di India mendapatkan kelompok umur terbanyak adalah 55 tahun $(75 \%)$.

Hasil yang didapat peneliti terlihat kelompok umur terbanyak hampir sama dengan yang diteliti oleh Harjono dan tidak berbeda jauh dengan peneliti lainnya. Perbedaan umur oleh masing-masing peneliti lebih didasari oleh cara pengelompokkan umurnya.

Berdasarkan distribusi kelompok pekerjaan penderita yang terlihat pada Tabel 4.4, peneliti melihat bahwa banyak penderita yang tidak tertulis jenis pekerjaannya dalam buku register di Bagian/SMF THT-KL RSU Prof. dr. R. D. Kandou Manado periode Januari 2010Desember 2012. Sedangkan melihat dari angka kejadian yang ditemukan peneliti dimana pekerjaan penderita terbanyak adalah pensiunan $13,2 \%$, diikuti oleh petani $10,2 \%$ dan IRT sebesar $8,3 \%$.

Hal ini menunjukkan bahwa faktor yang dapat mempengaruhi timbulnya penyakit ini adalah pekerjaan dan kebiasaan hidup. Kemungkinan lain yang menyebabkan penderita kedua terbanyak adalah petani adalah faktor lingkungan, kontak terhadap zat karsinogen seperti bahan-bahan insektisida pertanian, sangat besar pengaruhnya terhadap kejadian tumor ganas kepala dan leher, serta kebiasaan memasak dengan bahan atau bumbu masak tertentu, yang berkaitan dengan profesi sebagai ibu rumah tangga. ${ }^{2}$

Pada penelitian ini juga dapat dilihat bahwa dari 231 kasus tumor kepala leher yang ditemukan yaitu sebanyak 210 penderita atau sebesar $91 \%$ dan 25 penderita diantaranya ditemukan suspek tumor kepala leher. Hal ini dikarenakan penderita belum melakukan pemeriksaan histopatologis. Dan dari 21 kasus yang melakukan pemeriksaan histopatologis, ditemukan bahwa gambaran histopatologis yang tersering adalah karsinoma sel skuamosa, yaitu sebesar 11 penderita $(4,7 \%)$.

Hasil penelitian ini hampir sama dengan penelitian yang dilakukan Adeyemi, dalam penelitiannya terhadap 778 kasus tumor ganas THT-KL, menemukan jenis histopatologi yang paling sering ditemukan adalah karsinoma sel skuamosa (66,7\%). Menurut Aminullah, secara histopatologis, 95\% tumor ganas THT-KL merupakan jenis squamous cell carcinoma. 5,6 
Pemeriksaan histopatologis untuk diagnosis pasti tumor kepala leher tidak dilakukan pada semua kasus dalam penelitian ini. saat penderita datang dengan gejala klinis tumor, dianjurkan untuk melakukan pemeriksaan histopatologis dan diberitahukan jika pemeriksaannya menunjukkan hasil positif, maka penderita harus dirujuk untuk penanganan atau pengobatan lebih lanjut.

Hal inilah yang membuat penderita enggan untuk melakukan pemeriksaan ini, karena adanya masalah biaya, sedangkan bila penderita enggan melakukan pemeriksaan histopatologis maka hasil diagnosis terkadang kurang pasti karena kurangnya pemeriksaan lanjut yang harus dilakukan oleh penderita.

Pada Tabel 4.6 terlihat lokasi tumor kepala leher adalah di nasofaring sebanyak 81 penderita $(35,1 \%)$, kemudian diikuti oleh tumor pada tumor laring 62 penderita $(26,9 \%)$, tumor hidung dan sinus paranasal 57 penderita $(24,6 \%)$.

Sihotang di RSUP H. Adam Malik Medan mendapatkan lokasi terbanyak adalah nasofaring 59,1\%, lukmantya di Malang mendapatkan lokasi terbanyak adalah nasofaring 93 penderita dari 210 sampel (44,29\%). Rifqi mengemukakan data yang dikumpulkannya dari rumah sakit umum di sepuluh kota besar di Indonesia bahwa frekuensi tumor hidung dan sinus paranasal adalah 9,3-25,3\% dari keganasan THT-KL dan berada pada peringkat kedua setelah tumor ganas nasofaring. ${ }^{2}$

Insidensi di RSUP Dr. Kariadi Semarang, lokasi terbanyak jenis keganasan terbanyak adalah karsinoma nasofaring $(71,1 \%)$ kasus yang merupakan tersering di daerah THT-KL, diikuti tumor ganas hidung dan sinus paranasal (18\%), tumor ganas laring (16\%) serta tumor ganas rongga mulut, tonsil, dan hipofaring dengan presentase rendah. ${ }^{7}$

Hasil dari peneliti yang terbanyak lokasinya di nasofaring kemudian menyusul tumor laring, tumor hidung dan sinus paranasal hampir sama dengan hasil yang dilakukan oleh peneliti-peneliti lain.

Kebanyakan penderita datang dengan stadium keluhan yang sudah parah dengan adanya gejala pertama berupa metastasis di nasofaring, itu disebabkan karena tumor ganas ini tidak mempunyai gejala yang spesifik, seringkali tanpa gejala sehingga hal ini menyebabkan keterlambatan dalam diagnosis dan terapi.

\section{SIMPULAN}

Berdasarkan hasil penelitian retrospektif yang telah dilakukan di bagian/SMF THT- KL RSU Prof. dr. R. D. Kandou Manado periode Januari 2010-Desember 2012 dapat ditarik kesimpulan sebagai berikut :

1. Insiden tumor kepala leher di bagian/SMF THT- KL RSU Prof. dr. R. D. Kandou Manado periode Januari 2010-Desember 2012 didapatkan sebanyak 231 penderita $(1,78 \%)$ yang terdiagnosis secara klinis dan/atau histopatologis dan/atau endoskopis sebagai Tumor Kepala Leher.

2. Angka kejadian tertinggi ditemukan pada penderita laki-laki

3. Kelompok umur terbanyak adalah pada umur 41-65 pada tumor kepala leher

4. Distribusi pekerjaan yang paling terbanyak adalah pensiunan 
5. Karsinoma sel skuamosa merupakan gambaran histopatologis yang paling sering ditemukan

6. Tempat lokasi tersering dari tumor kepala leher adalah nasofaring

\section{SARAN}

Perlunya penyempurnaan sistem pencatatan dan penyimpanan data pasien dan diharapkan penelitian ini dapat dijadikan sebagai langkah awal bagi peneliti-peneliti berikutnya dalam menentukan diagnosis tumor kepala leher.

\section{UCAPAN TERIMAKASIH}

Ucapan terima kasih disampaikan pada dr. O.C.P.Pelealu, SpTHT-KL, dr. Steward K. Mengko, SpTHT-KL dan dr. R.E.C. Tumbel SpTHT-KL dan pada semua pihak yang baik secara langsung maupun tidak langsung telah menumbuhkan ide atau gagasan dalam pemikiran penulis sehingga dapat menyelesaikan artikel ini.

\section{DAFTAR PUSTAKA}

1. Ballenger JJ. Penyakit Telinga, Hidung, Tenggorok, Kepala dan Leher (edisi-13). Binarupa Aksara. hal 429-30

2. Sihotang ZB. Ototoksisitas cisplatin pada kemoterapi tumor ganas kepala dan leher di RSUP. H. Adam Malik Medan. Diakses melalui: http://repository.usu.ac.id/bitstream/123456789/6422/1/08E00051.pdf

3. Robbins and Cotran. Pathologic basis of disease. Kumar, Abbas, fausto.Edisi-8. 2010

4. Muzakkir M. karakteristik tumor ganas telinga hidung tenggorok di SMF THT-KL RSUP H. Adam Malik Medan. Diakses melalui: repository.usu.ac.id/bitstream/123456789/31042/.../Chapter\%20II.pdf

5. Karakteristik Tumor Ganas Telinga Hidung Tenggorok Kepala Dan Leher Di SMF THT-KL RSUP H. Adam Malik Medan. Diakses melalui: http://repository.usu.ac.id/bitstream/123456789/31042/4/Chapter\%20II.pdf

6. Aminullah, Yusuf. Pengaruh kombinasi vit.C dan E dosis tinggi terhadap penurunan sistem hemopoetik penderita kanker kepala dan leher yang mendapat kemoterapi cisplastin. Bab 2. Diponegoro University. 2011. Diakses melalui: http://eprints.undip.ac.id/33872/3/Bab_2.pdf

7. Roezin A, Adham M. Tumor Telinga Hidung Tenggorok. Dalam : Soepardi EA, Iskandar N, Bashiruddin J, Restuti RD., penyunting. Buku Ajar Ilmu Kesehatan Telinga Hidung Tenggorok Kepala dan Leher. Edisi ke-6. Jakarta: FKUI, 2007. hal.162-94. 